\section{Enrichment of polyfunctional T cells in PsA synovial tissue. Response to: 'Polyfunctional TEM cells in psoriatic arthritis synovium skewed towards Th17 cells' by Raychaudhuri et al}

We read with interest the research letter by Raychaudhuri et al, which examines the frequencies of cytokine producing CD4+ memory $\mathrm{T}$ cells in psoriatic arthritis (PsA) and rheumatoid arthritis (RA) synovial fluid mononuclear cells (SFMC) compared with peripheral blood mononuclear cells (PBMC). ${ }^{1}$ The authors examined the frequencies of single cytokineproducing T cells, specifically interleukin (IL)-17A+, IL-22+, tumour necrosis factor $(\mathrm{TNF})+$, interferon gamma $(\mathrm{IFN} \gamma)+$ or IL-23R + and report that Th17 cells are enriched in PsA SFMC, while RA is skewed to a Th1-like profile. In our previous publication, Wade et $a l,{ }^{2}$ we reported the frequencies of both single cytokine-producing and multiple cytokine (polyfunctional)producing $\mathrm{T}$ cells, in addition to the frequencies of Th1, Th17 and exTh17 cells by using the Th17 lineage marker CD161. In our study, however, we reported these findings in synovial tissue biopsies from PsA patients, as opposed to PsA SFMC (reported by Raychaudhuri et al), demonstrating enrichment of polyfunctional $\mathrm{T}$ cells, specifically triple-positive cytokine-producing $\mathrm{T}$ cells isolated from PsA synovial tissue.

While discrepancies in immune cell frequencies and phenotypes have been reported between SFMC and synovial tissue, ${ }^{3}$ the study by Raychaudhuri et al report an increase in CD4+ IL-17a + T cells in PsA SFMC compared with PBMC, an observation which we also described in PsA synovial tissue. ${ }^{2}$ Moreover, Raychaudhuri et al also report a decrease in TNF $\alpha$ production in PsA SFMC compared with PBMC, similar to that observed in our study in PsA synovial tissue . ${ }^{2}$

However, we noted that while Radchaudhuri et al report the identification of polyfunctional T cells in PsA and RA, we believe these data should be interpreted cautiously. Radchaudhuri et al demonstrate an increase in a number of single cytokineproducing $\mathrm{T}$ cells, specifically IL23R, 1L-17A and IL-22 in PsA compared with RA, however, they do not show that these cytokines are being co-produced by the same $\mathrm{T}$ cells (ie, polyfunctionality). Polyfunctionality or co-production of multiple cytokines within the same T-cell population is best evaluated using advanced flow cytometric algorithm analysis. ${ }^{2}{ }^{4}$ In this manner, polyfunctionality within a specific $\mathrm{T}$ cell can be accurately analysed. Moreover, we reported that it is these polyfunctional $\mathrm{T}$ cells that correlate with disease activity for psoriatic arthritis (DAPSA) and not the single cytokine-producing $\mathrm{T}$ cell subsets. Additionally, when we used a PDE4 inhibitor in our ex vivo synovial tissue single cell cultures, again it was the polyfunctional T-cell population and not the single-producing cytokine populations which responded, suggesting that the polyfunctional $\mathrm{T}$ cells are significantly contributing to disease pathogenesis and response in PsA. Further studies by Radchaudhrui et al to examine polyfunctional $\mathrm{T}$ cells within their dataset in addition to the single positive cytokine-producing T cells which they have reported in their study would extend their current findings. This would allow the comparative evaluation of these polyfunctional effector memory $\mathrm{T}$ cells in the periphery versus site of inflammation providing additional insight into their potential role in autoimmune disease.

Interestingly, in addition to examining the synovial environment in PsA, the authors also examined $\mathrm{T}$ effector memory (TEM) cells within RA SFMC and report a more Th1-like profile. Previous studies by Basdeo et al report an accumulation of ex-Th17 cells or non-classical Th1 cells in RA SFMC. ${ }^{4}$ It is now known that Th17 cells can lose their ability to produce IL-17 and instead switch to predominantly producing IFN $\gamma .^{5}$ These ex-Th17 cells can no longer be distinguished from Th1 cells purely on the production of IFN $\gamma$, given that both subsets produce this cytokine in high amounts. Therefore, the Th17 plasticity marker CD161 is used to delineate Th1 cells (CD161IFN $\gamma+$ ) from ex-Th17 cells (CD161+ IFN $\gamma+$ ). Thus, future analysis of the IFN $\gamma+$ TEM population in the Raychaudhuri et al's study could be performed to ascertain through the use of CD161 expression if the RA SFMC in their study display increased levels of Th1 cells or non classical Th1/exTh17 cells.

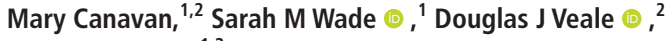 Ursula Fearon $\circledast^{1,2}$ \\ ${ }^{1}$ Molecular Rheumatology, Trinity Biomedical Sciences Institute, Trinity College Dublin, Dublin, Ireland \\ ${ }^{2}$ EULAR Centre of Excellence For Arthritis And Rheumatic Diseases, St. Vincent's University Hospital, Dublin, Ireland}

Correspondence to Professor Douglas I Veale, EULAR Centre For Arthritis And Rheumatic Diseases, University College Dublin, Dublin 4, Ireland; douglas.veale@ucd.ie

Handling editor Josef S Smolen

Twitter Mary Canavan @mary_canavan and Sarah M Wade @Sarah_M_Wade Contributors All authors contributed to the drafting and final approval of this research correspondence.

Funding The authors have not declared a specific grant for this research from any funding agency in the public, commercial or not-for-profit sectors.

Competing interests None declared.

Patient consent for publication Not required.

Provenance and peer review Commissioned; internally peer reviewed.

(c) Author(s) (or their employer(s)) 2020. No commercial re-use. See rights and permissions. Published by BMJ.

\section{Check for updates}

To cite Canavan M, Wade SM, Veale DJ, et al. Ann Rheum Dis Epub ahead of print: [please include Day Month Year]. doi:10.1136/annrheumdis-2019-216814

Received 19 December 2019

Revised 20 December 2019

Accepted 23 December 2019

\section{Linked}

- http://dx.doi.org/10.1136/annrheumdis-2019-216658

Ann Rheum Dis 2020;0:1. doi:10.1136/annrheumdis-2019-216814

\section{ORCID iDs}

Sarah M Wade http://orcid.org/0000-0003-2179-3903

Douglas I Veale http://orcid.org/0000-0003-2802-4971

Ursula Fearon http://orcid.org/0000-0001-8084-0429

\section{REFERENCES}

1 Raychaudhuri SK, Abria C, Raychaudhuri SP. Polyfunctional TEM cells in psoriatic arthritis synovium skewed towards Th17 cells. Ann Rheum Dis 2019. doi:10.1136/ annrheumdis-2019-216658

2 Wade SM, Canavan M, McGarry T, et al. Association of synovial tissue polyfunctional T-cells with DAPSA in psoriatic arthritis. Ann Rheum Dis 2019;78:350-4.

3 Hanlon MM, Canavan M, McGarry T, et al. Distinct macrophage phenotype and bioenergetic profiles in rheumatoid arthritis. Ann Rheum Dis 2019;78:A1-83.

4 Basdeo SA, Cluxton D, Sulaimani J, et al. Ex-Th17 (nonclassical Th1) cells are functionally distinct from classical Th1 and Th17 cells and are not constrained by regulatory T cells. J Immunol 2017;198:2249-59.

5 Annunziato F, Cosmi L, Liotta F, et al. Defining the human T helper 17 cell phenotype. Trends Immunol 2012;33:505-12. 